\title{
Postcolonial Studies in the Twenty-first Century: A Book Review Article about New Work by Ashcroft, Mendis, McGonegal, Mukerjee and Carrera Suárez, Durán Almarza, Menéndez Tarrazo
}

\author{
Alejandra Moreno \\ University of Oviedo
}

Follow this and additional works at: https://docs.lib.purdue.edu/clcweb

Part of the American Studies Commons, Comparative Literature Commons, Education Commons, European Languages and Societies Commons, Feminist, Gender, and Sexuality Studies Commons, Other Arts and Humanities Commons, Other Film and Media Studies Commons, Reading and Language Commons, Rhetoric and Composition Commons, Social and Behavioral Sciences Commons, Television Commons, and the Theatre and Performance Studies Commons

Dedicated to the dissemination of scholarly and professional information, Purdue University Press selects, develops, and distributes quality resources in several key subject areas for which its parent university is famous, including business, technology, health, veterinary medicine, and other selected disciplines in the humanities and sciences.

CLCWeb: Comparative Literature and Culture, the peer-reviewed, full-text, and open-access learned journal in the humanities and social sciences, publishes new scholarship following tenets of the discipline of comparative literature and the field of cultural studies designated as "comparative cultural studies." Publications in the journal are indexed in the Annual Bibliography of English Language and Literature (Chadwyck-Healey), the Arts and Humanities Citation Index (Thomson Reuters ISI), the Humanities Index (Wilson), Humanities International Complete (EBSCO), the International Bibliography of the Modern Language Association of America, and Scopus (Elsevier). The journal is affiliated with the Purdue University Press monograph series of Books in Comparative Cultural Studies. Contact: <clcweb@purdue.edu>

\section{Recommended Citation}

Moreno, Alejandra. "Postcolonial Studies in the Twenty-first Century: A Book Review Article about New Work by Ashcroft, Mendis, McGonegal, Mukerjee and Carrera Suárez, Durán Almarza, Menéndez Tarrazo." CLCWeb: Comparative Literature and Culture 16.3 (2014): <https://doi.org/10.7771/1481-4374.2518>

This text has been double-blind peer reviewed by $2+1$ experts in the field.

The above text, published by Purdue University Press (CPurdue University, has been downloaded 2279 times as of $11 /$ $07 / 19$.

This document has been made available through Purdue e-Pubs, a service of the Purdue University Libraries. Please contact epubs@purdue.edu for additional information.

This is an Open Access journal. This means that it uses a funding model that does not charge readers or their institutions for access. Readers may freely read, download, copy, distribute, print, search, or link to the full texts of articles. This journal is covered under the CC BY-NC-ND license. 


\section{PURDUE}

U N I V E R R S I T Y Y UNIVERSITY PRESS < http://wWw.thepress.purdue.edu>

\section{CLCWeb: Comparative Literature and Culture}

ISSN 1481-4374 <http://docs.lib.purdue.edu/clcweb> Purdue University Press (CPurdue University

CLCWeb: Comparative Literature and Culture, the peer-reviewed, full-text, and open-access learned journal in the humanities and social sciences, publishes new scholarship following tenets of the discipline of comparative literature and the field of cultural studies designated as "comparative cultural studies." In addition to the publication of articles, the journal publishes review articles of scholarly books and publishes research material in its Library Series. Publications in the journal are indexed in the Annual Bibliography of English Language and Literature (Chadwyck-Healey), the Arts and Humanities Citation Index (Thomson Reuters ISI), the Humanities Index (Wilson), Humanities International Complete (EBSCO), the International Bibliography of the Modern Language Association of America, and Scopus (Elsevier). The journal is affiliated with the Purdue University Press monograph series of Books in Comparative Cultural Studies. Contact: <clcweb@purdue.edu>

Volume 16 Issue 3 (September 2014) Book Review Article 16 Alejandra Moreno,

"Postcolonial Studies in the Twenty-first Century:

A Book Review Article about New Work by Ashcroft, Mendis, McGonegal, Mukerjee and Carrera Suárez, Durán Almarza, Menéndez Tarrazo"

<http://docs.lib.purdue.edu/clcweb/vol16/iss3/16>

Contents of CLCWeb: Comparative Literature and Culture 16.3 (2014)

Including Thematic Cluster Love, Sexualities, and Marriage in Literature

<http://docs.lib.purdue.edu/clcweb/vol16/iss3/> 
Alejandra Moreno, "Postcolonial Studies in the Twenty-first Century: A Book Review Article about New Work by

\section{Alejandra MORENO}

\section{Postcolonial Studies in the Twenty-first Century: A Book Review Article about New Work by Ashcroft, Mendis, McGonegal, Mukerjee and Carrera Suárez, Durán Almarza, Menéndez Tarrazo}

Much has been written since the turn of the new century about the effects of colonization and this helped to consolidate the field of postcolonial studies with theories of globalization including perspectives of cosmopolitanism and the field of (im)migration and diaspora studies (see, e.g., Appiah; Beck; Braidotti, Hanafin, Blaagaard; Brennan; Cheah and Robbins; Dagnino; Gupta; Krishnaswamy and Hawly; McClennen; Nava; Schoene; Spencer; Sturm-Trigonakis; Walkowitz; for a bibliography of postcolonial studies see Tötösy de Zepetnek, "Selected Bibliography"

<http://docs.lib.purdue.edu/clcweblibrary/postcolonialbibliography>). In 1995 Bill Ashcroft, Gareth Griffiths, and Helen Tiffin argued in their introduction to The Post-colonial Studies Reader that "Postcolonial studies are based in the 'historical fact' of European colonialism, and the diverse material effects to which this phenomenon gave rise. We need to keep this fact of colonization firmly in mind because the increasingly unfocused use of the term 'post-colonial' over the last ten years to describe an astonishing variety of cultural, economic and political practices has meant that there is danger of its losing its effecting meaning altogether" (2). It is in the 2006 introduction to the second edition of The Post-colonial Studies Reader where the editors argue that while the term postcolonial still stands for "both the material effects of colonization and the huge diversity of everyday and sometimes hidden responses to it throughout the world" (2-3), postcolonial theory has seen an increase in the variety of fields and disciplines that employ the term: "while post-colonial theory was a creation of literary study, it has provided a methodology for this wide range of disciplines" (5).

In 2007, Patricia Yaeger published what Sunil Agnani, Fernando Coronil, Gaurav Desai, Mamadou Diouf, Simon Gikandi, Susie Tharu, and Jennifer Wenzel discussed in the 2006 Modern Language Association of America annual convention round table "The End of Postcolonial Theory?" The participants' objective was to figure out the meaning of what many addressed as the "end of postcolonial theory." Their conclusion can be summed up as the need to open the field rather than focus on established and standard perceptions of what postcolonial studies would be (638). Some scholars believe that postcolonial studies is being eclipsed by globalization studies and others advocate for interdiscursive and interdisciplinary approaches so as to go "beyond a certain kind of postcolonial studies" (Lomba, Kaul, Bunzl, Burton, Esty 7). Revathi Krishnaswamy and J.C. Hawly conclude that "to be global is first and foremost to be postcolonial and to be postcolonial is always already to be global" (3). It is true that postcolonial studies has moved away from areas of regional studies to fields such as the social sciences or media studies, among others and all in the pursuit of new configurations and re-routings of knowledge where dynamism, critical theory, and relevance must always be present (e.g., on the application of postcolonial theory to Central and East European cultures, a concept much resisted until recently, see Tötösy de Zepetnek, "Cultures"; Berlina and Tötösy de Zepetnek). Dennis Walder asked in his 1998 Post-Colonial Literatures in English whether if there is an "after" postcolonial space, maybe it will be constructed as in Michael Ondaatje's The English Patient: "As a self-consciously selfreferential mosaic of moments in the present and past-a structure repeatedly reinforced in the narrative by the images of Italian frescoes and other forms of fragmentary or ruined art-yet a structure interfered with by personal memories and historical event, in short by the changing world ... yet their multiplicity of identities suggests the direction post-colonial literary studies may go: recasting histories to create a set of achronic narratives which reach back and (allegorically at least) forward in order to rechart the world, testifying to what Ondaatje through the patient calls 'our communal histories. Communal books'" (207-08; on the postcolonial in Ondaatje's work see, e.g., Tötösy de Zepetnek, Comparative Cultural).

Ato Quayson, when dealing with dimensions of interdisciplinarity in postcolonial studies, distinguishes between "synoptic" (concept) and "instrumental" (application). According to Quayson, postcolonial studies have been "highly interdisciplinary in the synoptic sense, borrowing freely from a wide range of fields in a desire both to challenge received assumptions as well as to shed light on the configurations of the present and the future" (25). In my view, contributors to the collected volumes Lit- 
erature for Our Times: Postcolonial Studies in the Twenty-first Century edited by Bill Ashcroft, Ranjini Mendis, Julie McGonegal and Arun Mukherjee (for a review of the volume see Alonso Breto) and Reading Transcultural Cities edited by Isabel Carrera Suárez, Emilia Durán Almarza, and Alicia Menéndez Tarrazo follow Quayson's approach in applying interdiscursive rather than interdisciplinary methodology. Nevertheless, studies in both volumes still imply "a crossing of traditional disciplinary boundaries" (Huggan 14).

Literature for Our Times is a compilation of papers presented at the 14th International Conference of the Association for Commonwealth Literature and Language Studies held in Vancouver in 2007. The question the volume addresses is: what is the field of postcolonial studies beginning to look like in the twenty-first century? Contributors to the volume define the field and whether it remains within observable boundaries. In their introduction to the volume the editors highlight how the postcolonial is a way or reading and how postcolonial theory provides the language to describe the diversity of cultures and the intersection of its global cultural production (xvi). The volume gives the reader a clear sense of the wide range of postcolonial concerns today with each section about an already existing area of interest within the field and approaching "emerging" subjects such as affect studies, autobiography, Dalit studies, diaspora studies, gender studies, Indigenous studies, linguistics, (im)-migration studies, Orientalism, transcultural theory, transnationalism, trauma studies, translation studies, etc. The editors define postcolonial studies positing that "it is not a Grand Theory of everything but a range of interests and approaches living together in what Amartya Sen might call an argumentative democracy" (xvii). The volume contains nine thematic sections structured with a variety of clusters which avoid the geographical approach. This is in my view important: Gregory Castle, in his 2001 Postcolonial Discourse followed a geographical approach based on a selection of regions in order to suggest heterogeneity and historical embeddedness of postcolonial discourses in geographical spaces and because at the turn of the century "theorizing postcoloniality is ineluctably tied to specific geographical, social, and historical conditions" (xiv).

If for Ashcroft, Mendis, McGonegal, and Mukherjee the consequences of a history of boundarycrossing is the congenital habit among postcolonial scholars of questioning the existing formulations of the field (xxi), no doubt this is what the contributors to the volume do. In the first chapter, entitled "The Idea of (Postcolonial) Literature: Conceptual and Methodological Issues," Frank Schulze-Engler and Debjani Ganguly begin the cluster by analyzing a topic currently of much interest - mostly in USAmerican scholarship - namely world literature (on world literatures [note the plural], see, e.g., Boruszko and Tötösy de Zepetnek <http://docs.lib.purdue.edu/clcweb/vol15/iss6/>; Damrosch; Juvan <http://docs.lib.purdue.edu/clcweb/vol15/iss5/>; Tötösy de Zepetnek and Mukherjee). SchulzeEngler assesses the place of postcolonial studies in relation to world literature and criticizes postcolonial studies of not having been able to produce "the most basic consensus about the shape of this metadiscipline" and thus, "postcolonial" has becomes a successor term for both "Commonwealth" and "Third World" (7; on varieties of "third world" studies see, e.g., DeSousa, Henton, Ramanathan <http://docs.lib.purdue.edu/clcweb/vol12/iss2/>; for a bibliography of "third world" studies see DeSousa <http://dx.doi.org/10.7771/1481-4374.1604>). In turn, Ganguly considers that "to read the 'world' in literature today is, thus, to confront both plurality and the prevalence of difference, and a myriad of often unpredictable nodes of connectivity" (33). Lincoln Z. Shlensky and Paul Sharrad approach the changing field by analyzing specific works. Shlensky shows how Jamaica Kincaid's literary work has the capacities of ethics via the autobiographical and Sharrad suggests the need for transformation in the field and underlines that there is a danger within postcolonial theory by textual-cultural abstractions which seem esoteric or irrelevant: Sharrad discusses Marcus Zusak's The Book Thiefand places affect theory as a relevant extension of boundery-crossing in postcolonial studies. Nela Bureu Ramos closes this section by discussing Robert Kroetsch's The Hornbooks of Rita K., and how his work together with the study of other postcolonial texts should balance between time and space in postcolonial writing.

Following conceptual and methodological issues, in chapter two entitled "After Said: Imperial Scholarship, Race, and Ethnicity" Daniel Sanjiv Roberts advocates closer attention to the roots of postcolonialism and Satish C. Aikant discusses the problem of overly generalized conceptualization of history (for a bibliography of Said's work see Callaghan <http://dx.doi.org/10.7771/14814374.1203>). The next chapter, entitled "Translations and Transformations," is about the role of 
translation in postcolonial studies. Ngũgĩ wa Thiong'o suggests that translation is a key mode of negotiating the universal and the particular and advocates moving away from nation-centric conceptions of culture via translation as a vital tool of globalization. John Hawley and Mumia Osaaji explore Ngũgĩ's work and the role of translation and Elena Basile explores how language can be the site of cultural healing through translation. And in the last article of the chapter Robert Young argues that "however wide the spread of the language, to write or read in English is not the same all over the world" since "rhizomatic contact occurs, transforming the languages in the process" (169).

Diaspora, (im)migration, transnationalism, and transculturalism are themes in the fourth chapter of the volume entitled "Literatures of Diaspora and Migrancy." Sissy Helff proposes transculturality as a way to global literatures and argues that an alliance of postcolonial criticism and transcultural studies is needed. John Clement Ball's discusses the ocean as a space that represents diasporic identity "and it is that relational identity that makes this sea-hating and sea-fearing man a creature of the ship, even as he and his story plant themselves firmly on the national shore that the latest critical waves keep threatening to wash away" (218). Anjali Roy explores the importance of bhangra music in Punjabi culture. Dorothy Lane examines the connection between India as a land of pilgrimage for both Indian and Western travelers and Kavita Ivy Nandan presents a personal account of the human consequences of racism against indentured Indian laborers transported to Fiji. Nandan underlines how writing becomes a healing power since "although I realize that the diasporic life assumes the quality of brokenness, writing has been a way to make meaning out of the rupture of the past" (274).

Gender studies, an important intersection in postcolonial studies, is present in the volume with a chapter entitled "Gendered Bodies." Cheryl Stobie analyzes Chimanda Adichie's Purple Hibiscus in the context of Black African feminism (on recent work on Black African literatures and cultures see, e.g., Black African <http://docs.lib.purdue.edu/clcweb/vol15/iss1/>). Marilyn Adler Papayanis discusses the place of gender in the relationship between trauma and testimony and Feroza Jussawala revisits the debate about the right to choose the veil as a statement of Muslim identity and for Jussawala wearing the veil represents resistance to homogenizing Western influences. She emphasizes how Muslim women have written both pro and contra this issue, "but they wanted to be, and continue to be, the one who wish to speak their own mind on this issue, rather than having it legislated either by Western notions or by feminisms" (293). In chapter six entitled "Indigenous Literatures, Literatures of the Land: An Ethos for These Times" Jeannette Armstrong shows how the stories of the Sylix Native American relationship with land can provide an ethos for contemporary questions of sustainability (on recent work about Indigenous literatures and cultures, see, e.g., O'Neill and Braz, About Indigenous <http://docs.lib.purdue.edu/clcweb/vol13/iss2/>; see also O'Neill and Braz, "Bibliography"

<http://dx.doi.org/10.7771/1481-4374.1749>). Sam McKegney and Michaela Moura-Koçoglu explore the pressure on Indigenous men to be and to perform in masculine stereotypes. Chelva Kanaganayakam and Stephen Ney introduce an area little explored by postcolonial studies: Philippine literature. Kanaganayakam underlines how this literature shares much in common with other postcolonial literatures and Ney takes the discussion to a connection between Christianity and the "postcolonization of Christianity" (406).

The last three chapters of the volume are about specific subjects such as "Dalit Literature and Its Criticism," "The City," and "Terrorism, Trauma, Loss." I note that especially in the chapter about the city, contributors engage with each other's ideas which is less present in other chapters. K.A. Geetha, P. Sivakami, and K. Stayanarayana explore matters of caste, gender, representation, and the political and organizational growth of Dalit identity and literature. The inclusion of this chapter represents a less studied theme in postcolonial studies. The is also the case with regard to the city, which has been absent in postcolonial theory until recently and it is the global phenomenon of (im)migration that attracts scholars to study intersections of the city and its people in postcolonial reading (on various aspects of the city in its various loci and formations see, e.g., Lisiak; López-Varela Azcárate and Net). "The City" chapter contains Pamela McCallum's article in which she explores the contemporary multicultural city within contemporary Britain by analyzing Zadie Smith's novels. The article is preceded by Vandana Saxena's and Angelie Multani's studies about English public schools by analyzing J.K. Rowling's Harry Potter novels. In the chapter "Terrorism, Trauma, Loss" there are the following articles: Fred Ribkoff discusses colonial trauma and mourning in the aftermath of the Air India bombing in the 1980s, Susan Spearey compares two stories of social and political transition in Rwanda and South 
Alejandra Moreno, "Postcolonial Studies in the Twenty-first Century: A Book Review Article about New Work by

Africa, Summer Pervez examines Hannif Kureishi's work and warns that "we have been failing to hear Kureishi's message for at least two decades, and this very failure has left us shocked in the wake of the 2005 London Bombs" (562), and Pilar Somacarrera urges us to take into account the social contents of Margaret Atwood's writing so as to understand her work. The volume proves that we are not facing a diminishing presence of postcolonial studies since "few research fields can be as contested, not least by their own practitioners, as Postcolonial Studies, which continues to share every inclination to choose itself as the principal object of its own debate" (Huggan 1).

The volume edited by Carrera Suárez, Durán Almarza, and Menéndez Tarrazo, Reading Transcultural Cities, is an example of the engagement in the ongoing processes of cultural decolonization. The geographical approach in the volume provides an interdiscursive link that joins theories of poststructuralism and postcolonialism in the pursuit of social and cultural change. Its focus is on literary representations of the global/gendered city. All articles gathered in the volume bring together theoretical and critical reflections on contemporary urban texts from cities as disperse as London, Vancouver, Dublin, and Havana. The work follows Manuel Castells's definition of the global city, a fluid an ever-changing concept he put forward in his 1977 The Urban Question. Most of the articles focus on European and Anglo-American geographies, but are all connected to neo/colonial routes, often exploring aspects of diaspora. That is why there is a persistence of the physical/(im)migrant human body, such as in Luz Mar González Aria's article in which she examines - using Elizabeth Grosz's concept of bodies-cities and Paula Meehan's concept of citified embodiments: "the embodied dimension of the city and the citified character of its dwellers conceptualise both humans and spaces as (inter)active agents of cultural production" (124).

The volume contains ten articles and a text of life-writing by gLoria (sic) Caballero Roca in which she reflects on the racial background that persists in Cuba and which constitutes a "decisive factor, together with gender, when defining who has really profited from the fruits of the Cuban revolutionary process" (246). This life story is preceded by Luisa Campuzano's article about the broader Latino framework and postnational condition. Campuzano's study is an example of how it is not only the "conventional partners in the British colonial relationship who are joined together in migrant writing in English" (Boehmer 228), but the ex-colonies of Spain such as Cuba, too. The editors' introduction is a review of the historical antecedents of the postcolonial urban from the old colonized cities to current postcolonial urban subjectivities. Rashmi Varma's article is about how postcolonial city "is constituted by the tensions and contradictions between the global, national and the local concepts and practices of urban space; it can therefore be conceptualized as a conjunctural space" (28). Aritha Van Herk analyzes the possibilities and limitations of the voyeur, particularly women: "the public and the private is thus no longer distinct, and that continual exploration of the luminal space that the window dramatises is key to the transcultural city" (47) since in the fenestration of the city, women whom we glimpse become texts of transculturalization (56). Following Marc Augé's concepts in his 2003 Pour quoi vivons-nous? Gabriele Griffin discusses the culture of South Asian communities in the United Kingdom and concludes that their urban reality is a non-place owing to the structural circumstances of their gendered and radicalized lives. Authors in the following three chapters discuss the cultures and peoples of Dublin, Aberdeen, and London: Katherine O'Donnell, Luz Mar González Arias, and Carla Rodríguez González analyze how cities are subjects in process where the alternative geographies which literature provides are needed to inscribe new spaces for subjects on the move. Elizabeth Russell, Alicia Menéndez Tarrazo, and Esther Álvarez López discuss the cultures of Mumbai, Vancouver, Puerto Rico, and New York by analyzing literary texts which deconstruct the city and its native inhabitants, permanent residents, and those in transit. Relevant is that articles in the volume refer to specific global/local loci and thus Reading Transcultural Cities offers a conceptual basis for an interdiscursive framework. Contributors to the volume dialogue with each other and thus the volume represents intellectual and thematic coherence.

In conclusion, while some areas of postcolonial studies are underrepresented or missing in both volumes, the scholarship presented provides opportunities to redefine the field. They offer readers complex models of what might be called "tidalectics"-term coined by Kamau Brathwaite in 1967which suggests a cyclic, rhizomatic motion that breaks with Eurocentric theory formation and argues instead for a global interdiscursive conceptualization. Scholarship presented in Literatures for Our Times and Reading Transcultural Cities disrupts monolithic ideologies and advances the global imagi- 
nary-and hopefully practice-towards inclusion and this is important for the social relevance of the study of culture and literature.

\section{Works Cited}

Alonso Breto, Isabel. Rev. of Bill Ashcroft, Ranjini Mendis, Julie McGonegal and Arun Mukherjee, eds. 2012: Literature for Our Times: Postcolonial Studies in the Twenty-first Century. Amsterdam and New York: Rodopi. Atlantis: Journal of Spanish Association of Anglo-American Studies 35.2 (2013): 219-25

Appiah, Anthony Kwame. Cosmopolitanism: Ethics in a World of Strangers. New York: Norton, 2006.

Ashcroft, Bill, Gareth Griffiths, and Helen Tiffin. The Post-Colonial Studies Reader. 1995. Oxford: Routledge, 2006.

Ashcroft, Bill, Ranjini Mendis, Julie McGonegal, and Arun Mukherjee, eds. Literatures for Our Times: Postcolonial Studies in the Twenty-first Century. Amsterdam: Rodopi, 2012.

Augé, Marc. Pour quoi vivons-nous? Paris: Fayard, 2003.

Beck, Ulrich. The Cosmopolitan Vision. Trans. Ciaran Cronin. Cambridge: Polity P, 2006.

Berlina, Alexandra, and Steven Tötösy de Zepetnek. "Comparative Literature in Russian and in Central and East Europe." Companion to Comparative Literature, World Literatures, and Comparative Cultural Studies. Ed. Steven Tötösy de Zepetnek and Tutun Mukherjee. New Delhi: Cambridge UP India, 2013. 337-52.

Black African Literatures and Cultures. Thematic Cluster CLCWeb: Comparative Literature and Culture 15.1 (2013): $<$ http://docs.lib.purdue.edu/clcweb/vol15/iss1/>.

Boehmer, Elleke. Colonial and Postcolonial Literature. 1995. Oxford: Oxford UP, 2005.

Boruszko, Graciela, and Steven Tötösy de Zepetnek, eds. New Work about World Literatures. Special Issue CLCWeb: Comparative Literature and Culture 15.6 (2013): <http://docs.lib.purdue.edu/clcweb/vol15/iss6/>.

Braidotti, Rosi, Patrick Hanafin, and Bolette B. Blaagaard, eds. After Cosmopolitanism. London: Routledge, 2013.

Brathwaite, Kamau. "Jazz and the West Indian Novel." 1967. Roots. By Kamau Brathwaite. Ann Arbor: U of Michigan $\mathrm{P}, 1993.55-110$.

Brennan, Timothy. At Home in the World: Cosmopolitanism Now. Cambridge: Harvard UP, 1997.

Callaghan, Clare. "Selected Bibliography of Work about and of Edward Said's Texts." CLCWeb: Comparative Literature and Culture 5.4 (2003): <http://dx.doi.org/10.7771/1481-4374.1203>.

Castells, Manuel. The Urban Question. London: Arnold, 1977.

Castle, Gregory, ed. Postcolonial Discourse: An Anthology. Oxford: Blackwell, 2001.

Carrera Suárez, Isabel, Emilia Durán Almarza, and Alicia Menéndez Tarrazo, eds. Reading Transcultural Cities. Palma: U of Illes Balears, 2011.

Cheah, Pheng, and Bruce Robbins, eds. Cosmopolitics: Thinking and Feeling Beyond the Nation. Minneapolis: U of Minnesota $\mathrm{P}, 1998$.

Dagnino, Arianna. Transcultural Writers and Novels in the Age of Global Mobility. West Lafayette: Purdue UP, 2015. Forthcoming.

Damrosch, David. What Is World Literature? Princeton: Princeton UP, 2003.

DeSousa, Valerian. "Bibliography of Work in Modernity and 'Third World' Studies." CLCWeb: Comparative Literature and Culture 12.2 (2010): <http://dx.doi.org/10.7771/1481-4374.1604>.

DeSousa, Valerian, Jennifer E. Henton, and Geetha Ramanathan, eds. New Modernities and the "Third World." CLCWeb: Comparative Literature and Culture 12.2 (2010): <http://docs.lib.purdue.edu/clcweb/vol12/iss2/>

Grosz, Elizabeth. "Bodies-Cities." Sexuality and Space. Ed. Beatriz Colomina. Princeton: Princeton Architectural P, 1992. 241-53.

Gupta, Suman. Globalization and Literature. London: Polity P, 2009.

Huggan, Graham. Interdisciplinarity Measures: Literature and the Future of Postcolonial Studies. Liverpool: Liverpool UP, 2008.

Juvan, Marko, ed. World Literatures from the Nineteenth to the Twenty-first Century. Special Issue CLCWeb: Comparative Literature and Culture 15.5 (2013): <http://docs.lib.purdue.edu/clcweb/vol15/iss5/>.

Krishnaswamy, Revathi, and J.C. Hawly, eds. The Postcolonial and the Global. Minneapolis: U of Minnesota P, 2008.

Lisiak, Agata Anna. Urban Cultures in (Post)Colonial Central Europe. West Lafayette: Purdue UP, 2010.

Lomba, Ania, Suvir Kaul, Matti Bunzl, Antoinette Burton, and Jed Esty, eds. Postcolonial Studies and Beyond. London: Duke UP, 2005.

López-Varela Azcárate, Asunción, and Mariana Neţ, eds. Real and Virtual Cities: Intertextual and Intermedial Mindscapes. Bucure $\square$ ti: Univers Enciclopedic, 2009.

McClennen, Sophia A. The Dialectics of Exile: Nation, Time, Language, and Space in Hispanic Literatures. West Lafayette: Purdue UP, 2004.

Meehan, Paula. Dharmakaya. Manchester: Carcanet, 2000.

Nava, M. Visceral Cosmopolitanism: Gender, Culture and the Normalisation of Difference. Oxford: Berg, 2007.

O'Neill, Angeline, and Albert Braz. "Bibliography of Scholarship on Indigenous Literatures and Cultures." CLCWeb: Comparative Literature and Culture 13.2 (2011): <http://dx.doi.org/10.7771/1481-4374.1749>.

O'Neill, Angeline, and Albert Braz, eds. About Indigenous Literatures. Thematic Issue CLCWeb: Comparative Literature and Culture 13.2 (2011): <http://docs.lib.purdue.edu/clcweb/vol13/iss2/>.

Quayson, Ato. Postcolonialism: Theory, Practice or Process? Cambridge: Polity P, 2000.

Schoene, Berthold. The Cosmopolitan Novel. Edinburgh: Edinburgh UP, 2009.

Spencer, Robert. Cosmopolitan Criticism and Postcolonial Literature. London: Palgrave, MacMillan, 2011.

Sturm-Trigonakis, Elke. Comparative Cultural Studies and the New Weltliteratur. West Lafayette: Purdue UP, 2013.

Tötösy de Zepetnek, Steven. "Cultures, Peripheralities, and Comparative Literature." Comparative Literature: Theory, Method, Application. By Steven Tötösy de Zepetnek. Amsterdam: Rodopi, 1998. 121-73. $<$ http://docs.lib.purdue.edu/clcweblibrary/totosycomparativeliterature1998>.

Tötösy de Zepetnek, Steven. "Selected Bibliography of Theory and Criticism in Postcolonial Studies." Library Series CLCWeb: Comparative Literature and Culture: 
